\title{
BETWEEN COUNTRIES AND DREAMS
}

\section{Patrick D. Flores}

\section{About the Author}

Patrick D. Flores is a Professor of Art Studies at the University of the Philippines. He is also Curator of the Vargas Museum in Manila and Adjunct Curator at the National Art Gallery, Singapore. He was one of the curators of "Under Construction: New Dimensions in Asian Art" in 2000 and of the Gwangju Biennale (Position Papers) in 2008. He was a Visiting Fellow at the National Gallery of Art in Washington, D.C. in 1999 and an Asian Public Intellectuals Fellow in 2004. His publications include Painting History: Revisions in Philippine Colonial Art (1999); Remarkable Collection: Art, History, and the National Museum (2006); and Past Peripheral: Curation in Southeast Asia (2008). He was a grantee of the Asian Cultural Council (2010) and a member of the Advisory Board of the exhibition The Global Contemporary: Art Worlds After 1989 (2011) organized by the Center for Art and Media in Karlsruhe and member of the Guggenheim Museum's Asian Art Council (2011). He co-edited the Southeast Asian issue with Joan Kee for Third Text (2011). Recently, he was a Guest Scholar of the Getty Research Institute in Los Angeles in 2014. 
It was the pleasure of the Vargas Museum to be part of the occasion to launch the debut poetry collection, Histories, of Charlie Samuya Veric. As a curator of a university museum, I have always encouraged gatherings of both kindred and discrepant spirits across creative forms. The night before the launch, we had opened the exhibition Terraforming, presenting the work of ceramic artists Mark Valenzuela and Pablo Capati III. And perhaps this setting was perfect for the launching of a book that is also ceramic in many ways: painstakingly shaped, highly fired, sometimes glazed and ornamented, sometimes bare, but always a vessel.

Veric was in my Humanities class when I was a very young instructor. He struck me as a bit ponderous but also quite intrepid. He once asked me, for instance, if I was really a Marxist, a tough one for which I have no real answer. And there was this episode at Yale. He took me around the campus and we ended up in a bookstore. He headed for the toilet and found the men's room locked; so he went to the women's room as a matter of instinct as it was of necessity. A customer complained to the store clerk, who went up to the trespasser for an explanation. The understandably baffled clerk got a lecture instead on the history of segregation, beginning with race and progressing to gender. This kind of temerity animates, stirs the book.

Trust Veric, therefore, to be impertinent even in the untimely, like in the intractable poetic time that he deems selfless only because it is indifferent, potent because it cannot be merely importuned. At the heart of this effort is the elusive poetics that frames and permeates the writing. It is rather extenuate, as Shakespeare would phrase it, though haltingly so, presaged by a chronicle in the historical annals and then foraying into a world of fellow writers like him whose métier is always suspect, always subject to the idiocies of rural life. He reflects on the political ecology of this world and he does not like it; in fact, he disowns it and, in its stead, repossesses a different universe for his écriture, his critical, because finally timely, écriture.

I am no literary critic and I will not even attempt to respond to the poetic gesture. But I am interested in the anxiety that unhinges it so that it becomes restive, unrelenting in its questions, and diligent in its desire to lay bare the workings of a literary world to which he does not wish to belong and tempts others to do the same. He has never been a native of this clearing and so no allegiance whatsoever is honored and no burdens of separation need be belabored. It is a literary world that has in his mind become a bureau, a cabal, an instrument of a profession. I just wonder, however, if such a profession has totally nothing to do with the distinction of poetry as a particular artifice, in fact a specific intelligence of which the poet Veric partakes. Is it not the same theoretical technology that lets him predicate his poetics on Walter Benjamin, among other references? Is this archive of references part of the profession, too? Or is it accessed via another trajectory? 
This tension between negation and alterity is ever-present in contra-institutional claims like Veric's. In fact, it is apparent in the earlier phase of his explication. The literary historian and critic Oscar Campomanes asks, What does it mean for Veric to write poetry? The poet equivocates in his response. He answers with a counterquestion: "Why should a poet explain why he likes to write?" The interlocution is deftly evaded. For the question zeroed in on both meaning and effect and not merely on liking, though the verb like is likewise interesting. What does it mean for Veric to like to write poetry?

I think the answer lies in the sentimental education of a life in transition, an allegory of the poetic itself as irreducibly exilic: that it is always missing-and according to Veric, let the missing be poetics. Three poems flesh out this wistfulness quite cogently.

In "Singular Catastrophe," the quotidian is suspended between wintry Madison and cloudless Manila, between the coconuts of the tropics and the "newly dead" leaves of autumn, between "countries and dreams." This is the migrant's image of what a curator calls "intense proximities."

"Unhappier" is starker. Here, loneliness is at last described, caught in concretion: the "cold biting," the "bitter void," heedless of layers and therefore fully exposing even the most inveterate.

And in "If One of Those Fall Mornings," the persona disrupts the picturesque with a remembrance of a woman sailing in the Grenadines. The picturesque is thus inflected with melancholy so that it could dissolve into the rare patience of a poet who is moved to imagine that "somewhere life waited." It is upon sensing this "somewhereness" that the poet musters up his own agency to stake out a path and "to walk into the day."

And it might be this poetics of patience and agency, of at once being patient and being agent, that entitles Veric to write and anticipate histories of temerity. 